\title{
Andrzej Raszkowski
}

Wrocław University of Economics

e-mail: andrzej.raszkowski@ue.wroc.pl

ORCID: 0000-0002-0232-2148

\section{Elżbieta Sobczak}

Wrocław University of Economics

e-mail: elzbieta.sobczak@ue.wroc.pl

\section{DELIMITATION PROCEDURE OF DEGRADED AREAS AND THE AREA TARGETED FOR REVITALISATION}

\section{PROCEDURA DELIMITACJI \\ OBSZARÓW ZDEGRADOWANYCH \\ ORAZ OBSZARU REWITALIZACJI}

DOI: $10.15611 / \mathrm{e} 21.2018 .2 .03$

Summary: The study discusses problems related to identifying degraded areas and the area targeted for revitalisation in relation to the local government units (cities, municipalities, regions). The core part of the study presents an example of the typology of factors and crisis phenomena in a social, economic, spatial-functional, environmental and technical perspective. The delimitation procedure, based on the application of indicators describing the concentration of phenomena in the system of municipal urban units was discussed. Next the area targeted for revitalisation was characterised as part of the identified degraded areas. This was followed by characterising the degraded areas based on the conducted survey studies. In both cases the delimitation procedure is covered by a civic control scheme. Within the framework of general conclusions it can be adopted that the described procedures or similar ones are most frequently applied in relation to Polish local government units.

Keywords: revitalisation, delimitation procedure, socio-economic development, development policy, degraded area.

Streszczenie: W opracowaniu poruszone zostały zagadnienia związane z wyodrębnianiem obszarów zdegradowanych oraz obszaru rewitalizacji w odniesieniu do jednostek samorządu terytorialnego (miast, gmin, regionów). W głównej części opracowania zaprezentowana została przykładowa typologia czynników i zjawisk kryzysowych w wymiarach: społecznym, gospodarczym, przestrzenno-funkcjonalnym, środowiskowym oraz technicznym. Przedstawiono procedurę delimitacji opartą na wykorzystaniu wskaźników opisujących koncentrację zjawisk w układzie jednostek urbanistycznych gminy. Następnie opisano wyznaczenie obszaru rewitalizacji w ramach wybranych obszarów zdegradowanych. W kolejnym przykładzie scharakteryzowano wyznaczenie obszarów zdegradowanych, opierając się na przeprowadzonych badaniach ankietowych. W obydwu przypadkach procedura delimitacji objęta jest sche- 
matem kontroli obywatelskiej. W ramach wniosków można przyjąć, że opisane procedury są najczęściej stosowane w odniesieniu do polskich samorządów.

Słowa kluczowe: rewitalizacja, procedura delimitacji, rozwój społeczno-ekonomiczny, obszar zdegradowany, obszar rewitalizacji.

\section{Introduction}

One of the most important elements related to the process of revitalisation is the correct and relatively accurate identification of the areas which should be covered by the aforementioned revitalisation. Practically in every territorial unit there are areas requiring corrective actions, therefore it is important to select the ones which require them the most. Due to limited financial and organizational resources it is often impossible to revitalize all degraded areas. In light of these assumptions, the delimitation process covering both the degraded areas and the areas of revitalisation remains an important component of local development policy and may influence the pace of socio-economic changes.

The standard revitalisation process is carried out based on a strategic document, i.e. the local revitalisation programme, which defines the framework of the procedure and the schedule of activities. The programme essentially consists of the following parts: a socio-economic diagnosis of the territorial unit (social, economic, environmental, spatial-functional, technical sphere); a SWOT analysis; PESTEL; a problems tree [Allen 2001]; the diagnosis of factors and crisis phenomena in five mentioned spheres; the designation of degraded areas; identifying revitalisation areas within the degraded areas; the vision of the area condition following revitalisation; revitalisation goals; planned revitalisation effects; a list of basic revitalisation projects; a list of additional revitalisation projects; mechanisms ensuring complementarity between individual projects in the areas covered by revitalisation; social participation in revitalisation process; linking the programme to the other strategic and planning documents of the territorial unit; the system of implementation, monitoring and evaluation.

This is an example of a revitalisation programme system, which in relation to a specific municipality or a city can have a slightly different structure, corresponding to local preferences, e.g. an extended, added part related to the revitalisation of post-industrial, post-military, post-port, post-shipyard areas, etc.

It should also be mentioned that a revitalisation programme remains one of many strategic documents dedicated to local government units having a measurable impact on developing a policy focused on supporting sustainable development [Giorgetta 2002]. The basic documents include the municipal sustainable development strategy, however the environment protection programme, tourism development strategy, promotion strategy [Kotler et al. 1999], branding, the programme for historical monuments' protection, the study of determinants and directions for spatial development, low-emission economy plan and the strategy for solving social 
problems are also of major importance. Therefore revitalisation is a part of a broadly approached sustainable development, becoming its vital component [Bartniczak, Raszkowski 2017; Pawłowski 2011; Przybyła, Przybyła 2014; Raszkowski, Głuszczuk 2015].

The purpose of this study is to present selected methods aimed at the delimitation of degraded areas and the area ultimately identified for revitalisation. The methods characterised in the study are used for the majority of Polish local government units.

\section{Defining revitalisation}

Revitalisation can be approached as a coordinated process carried out jointly by the local government, local community, entrepreneurs [Sutton 2010; Mitchell 2001], representatives of non-governmental organizations and other actors [Ruffin 2010], as the component of development policy aimed at counteracting space degradation and crisis phenomena, stimulating development and quality changes through increasing social and economic activity, improving the living environment and protecting national heritage, along with maintaining the principles of sustainable development.

The term 'degraded area' can be understood as an area where a state of crisis has been identified. Most often it refers to urban areas, but can also cover rural areas. A degraded area can be divided into sub-areas, including the sub-areas without common boundaries, provided that an emergency situation is identified in each of these sub-areas. In turn, the revitalization area covers the whole or part of the degraded area, characterised by a particular concentration of negative phenomena, on which revitalization is planned due to its importance for local development [Fitzgerald, Leigh 2002; Głuszczuk, Raszkowski 2015]. The area of revitalization can be divided into sub-areas, including the sub-areas without common boundaries. It is usually covered by certain area restrictions and related to the number of inhabitants determined by their percentage and resulting from internal national and local government regulations.

In the theoretical approach to revitalization problems, complexity remains the crucial factor. Revitalisation oriented activities should cover at least the five key spheres listed in the introduction, often supplemented by the sphere of culture. The contribution of culture to the process of dynamising economic development and strengthening social structures may be greater than it might seem when taking superficial approach [Starr 2013]. Representatives of the business world, education, public authorities, and non-governmental organizations [Edwards, Hulme 1995] are more frequently beginning to perceive culture in the context of a significant development factor, also important in terms of revitalization processes.

Among all the analysed areas, the social sphere is the most important one, in other words we cannot discuss revitalization disregarding the aspect of social revival and social regeneration [Becker, Collins 2003]. One of the most common mistakes or misunderstandings is identifying the revitalization processes with technical 
aspects only. In such a situation we deal with restoration, reengineering, refinement, reconstruction, and renovation rather than revitalization.

\section{Selected methods for determining the degraded area and the area of revitalization}

The following part of the study characterises two methods for delimitation of the degraded areas and designated for comprehensive revitalization. The above-mentioned methods have a simplified formula and their different variants are applied in practice. At this point the universalism of these methods should be emphasized, i.e. they can be used in any local administration system. The lack of access to reliable public statistics or the inability to conduct survey studies among representatives of the local community can result in a bottleneck in the discussed case.

\subsection{The method based on indicators describing the concentration of negative phenomena}

The first stage on the path to separating the degraded areas is the division of a territorial unit (e.g. cities, municipalities) into urban units, which correspond to its functional and historical conditions. According to this division, all analyses regarding the intensity and concentration of crisis phenomena will be conducted. Urban units represent cohesive areas which can be distinguished as certain entities in social, morphological, functional and spatial terms. They do not always coincide with administrative boundaries, even though they function within them. The existing division into administrative units and statistical units does not always reflect the diversity of urban space and the functional-spatial areas developed within it - the community of which remains integrated. The division into urban units allows presenting informal structures and connections between the particular areas, and also facilitates the development of a more comprehensive diagnosis covering these areas, since the crisis situations and the problems of individual spheres overlap within the places linked in social, functional and spatial terms. The characteristic feature of urban units is the fact that they cover inhabited areas only. The separation of urban units alone remains of arbitrary and expert nature and is usually carried out by the local authorities.

A city, a municipality are thus divided into urban units, for example:

- Eastern Area (1),

- Western Area (2),

- Northern Area (3),

- Southern Area (4).

A comprehensive diagnosis of the factors, crisis phenomena in all the five (or more) spheres is carried out on the basis of quantitative data and the information predominantly collected from municipal offices, municipalities and local public 
statistics. For the purposes of this study the set of 17 indicators, referring to the concentration and intensity of crisis phenomena in the layout of urban units, was used. The number of indicators taken into account for analysis purposes may be higher, however, their considered number is relatively large. The general rule is that the most recent data are being used, but attention is paid to their availability, comparability and credibility.

The following indicators can be considered:

- total number of people covered by social aid (social sphere),

- number of families receiving care allowance (social sphere),

- number of carried out eviction cases (social sphere),

- total number of unemployed population (social sphere),

- total number of long-term unemployed population (social sphere),

- number of unemployed population under 25 years of age (social sphere),

- number of population aged $75+$ (social sphere),

- number of working age population (social sphere),

- number of non-governmental organizations (NGOs) (social sphere),

- number of crimes and offences (social sphere),

- total number of economic entities (economic sphere),

- number of economic entities, microenterprises (0-9 employees) (economic sphere),

- traffic noise level (environmental sphere),

- road infrastructure, roads in poor technical condition (spatial-functional sphere),

- number of historic monuments (technical sphere),

- buildings of housing communities, percentage of buildings in poor technical condition (technical sphere).

The standard concentration index, taking the form: [analysed characteristic in "X" unit / population number in "X" unit] / [analysed characteristic in a municipality / population number in a municipality] can be applied to perform calculations in the social and economic sphere. This index should be interpreted as follows:

- the value from 1.25 upwards stands for a very high concentration of the analysed phenomenon,

- the value between 1.00-1.24 stands for a high concentration of the analysed phenomenon,

- the value between 0.76-0.99 stands for a low concentration of the analysed phenomenon,

- the value from 0.75 and down stands for a very low concentration of the analysed phenomenon.

It can be accepted that a crisis situation occurs when the concentration index value remains within the range $100-1.24$, whereas 1.25 and above in terms of the characteristics is typical for destimulants. The value of 1.25 means that the level of the analysed phenomenon is $25 \%$ higher, within a given unit, than the mean value for the entire municipality, taking into account the number of urban unit inhabitants. In the case of characteristics representing stimulants, the index value at the level 
between 0.76-0.99 as well as 0.75 and below was adopted as typical for a crisis situation. In the analysed case four indicators represent stimulants: the number of working age (productive) population, the number of NGOs, the total number of business entities and the number of business entities and microenterprises.

In the environmental sphere (traffic noise level), the material from the reports of the institutions examining the readings of exceeded permissible traffic noise standards can be used. A crisis situation is diagnosed when the acceptable level is exceeded. Another indicator used in this area is the level of air pollution, assuming the possibility of its different levels in individual urban units.

The spatial-functional sphere (road infrastructure, roads in poor technical condition) is analysed for example on the basis of on-site verification and the internal materials of individual territorial government units. In the technical sphere the percentage division of municipal historic monuments and the number of housing communities' buildings in poor technical condition can be carried out by their allocation to urban units. When analysing the above-mentioned phenomena, i.e. the spatial-functional and technical spheres, the results exceeding $50 \%$ can be considered as a crisis situation.

After performing the necessary calculations a collective list is prepared, e.g. in a tabular form, indicating urban units characterised by the most frequent crisis situations. For example, in the Western Area it occurred 14 times out of a possible 17, and it happened more often than in other units. In this case the Western Area was qualified as degraded. Subsequently there are two options to follow. If possible, the entire degraded area simultaneously turns into a revitalized area, whereas in the second case, a smaller area is designated for revitalization within the degraded area (Western Area). Such a designation is usually based on on-site verifications, expert knowledge and social consultations. Alternatively, another indicator analysis is conducted on a smaller scale. A situation may take place in which two degraded areas are designated, and thus two revitalization areas within their boundaries. More such potential combinations are possible. During the entire procedure both city and municipality maps with marked urban units, degraded area/areas, revitalization area/ areas are used as a support.

\subsection{The method using survey studies}

In this case, the selection of degraded and revitalization areas is carried out in a more socialized way, based on the data collected in surveys involving residents of the entire area of a given municipality.

An exemple of such a procedure assumes using a questionnaire covering, by the scope of its questions, all the discussed spheres (social, economic, environmental, spatial-functional, technical). The distribution of the surveys is usually carried out electronically and by trained interviewers in the area of all previously separated urban units. The questionnaires can also be made available in a stationary form 
(e.g. in a municipal office). Each of the residents participating in a survey is asked, for instance, to indicate a minimum of one and a maximum of two areas in a municipality (out of the four separated), which in his/her opinion meet the criteria of degraded areas. Next, with reference to all the chosen areas, he/she evaluates the intensity of problems in particular spheres (on a 5-point scale, see Table 1). In this way the area/areas characterised by the greatest degradation, following the subjective evaluation of the residents, are being identified. Apart from the residents' views, the survey can also be used to study the opinions of entrepreneurs, representatives of non-governmental organizations and local government administration employees.

Table 1. An example list of problems in particular spheres, named in the survey questionnaire to determine the problem intensity (e.g. from 1 to 5 , where 5 stands for the highest intensity)

\begin{tabular}{|c|c|c|c|c|}
\hline Social sphere & Economic sphere & $\begin{array}{c}\text { Environmental } \\
\text { sphere }\end{array}$ & Spatial-functional sphere & Technical sphere \\
\hline 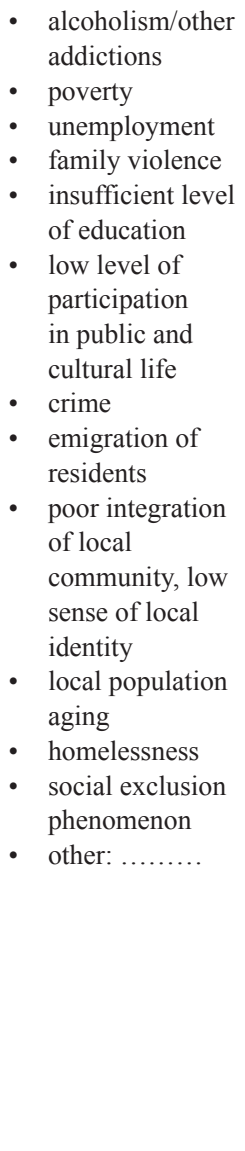 & 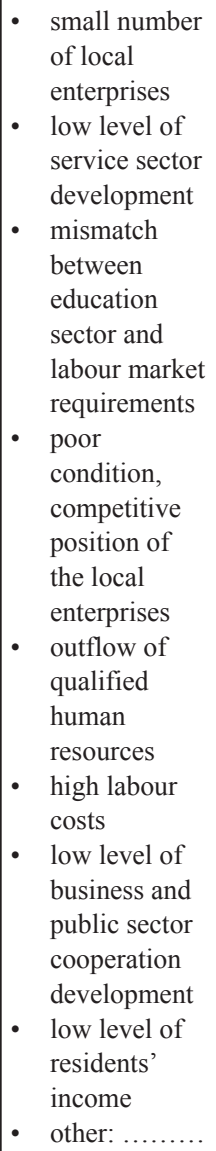 & $\begin{array}{ll}\text { - } & \text { poor air quality } \\
\text { - } & \text { manefficient waste } \\
\text { - } & \text { illegal landfills } \\
\text { poor water } & \text { quality } \\
\text { - } & \text { low level of } \\
\text { environmental } \\
\text { education } \\
\text { low share } \\
\text { of energy } \\
\text { production } \\
\text { from renewable } \\
\text { sources } \\
\text { presence of } \\
\text { waste posing } \\
\text { threat to human } \\
\text { health } \\
\text { contaminated } \\
\text { soil } \\
\text { high level of } \\
\text { traffic noise } \\
\text { other: ......... }\end{array}$ & $\begin{array}{l}\text { - absence of } \\
\text { comfortable meeting } \\
\text { places (a common } \\
\text { room etc.) } \\
\text { absence of recreation } \\
\text { and leisure areas } \\
\text { (e.g. bike paths, } \\
\text { playgrounds, green } \\
\text { areas) } \\
\text { low aesthetics of } \\
\text { public space } \\
\text { poor transport } \\
\text { facilities connecting } \\
\text { with the rest of the } \\
\text { municipality } \\
\text { condition/number of } \\
\text { roads and pavements } \\
\text { insufficient social } \\
\text { infrastructure } \\
\text { absence of } \\
\text { maintaining spatial } \\
\text { order } \\
\text { (kindergartens, } \\
\text { schools, health care, } \\
\text { culture centres) } \\
\text { other: ......... }\end{array}$ & $\begin{array}{l}\text { poor technical } \\
\text { condition of } \\
\text { buildings } \\
\text { absence of } \\
\text { energy-saving } \\
\text { solutions in } \\
\text { buildings } \\
\text { - neglected } \\
\text { historic } \\
\text { monuments } \\
\text { absence of } \\
\text { functioning } \\
\text { technical } \\
\text { solutions } \\
\text { allowing } \\
\text { effective usage } \\
\text { of buildings } \\
\text { (including } \\
\text { persons with } \\
\text { disabilities) } \\
\text { significant } \\
\text { share of old } \\
\text { housing stock } \\
\text { insufficient } \\
\text { technical } \\
\text { infrastructure } \\
\text { (energy, heat, } \\
\text { water, gas, } \\
\text { sewage) } \\
\text { other: ......... }\end{array}$ \\
\hline
\end{tabular}

Source: authors' compilation. 
The subsequent procedure is analogous to the method based on indicators, i.e. identifying the specific revitalization area is based on expert knowledge, the conducted social consultations, opinions of the representatives of the local authorities. If possible, the degraded area is entirely qualified for revitalization. Similarly to the indicator-based delimitation, various modifications and variants of the survey-based method are applied.

The major deficiency of this method is the subjective approach of the respondents involved in the study, which can be avoided to a large extent by applying indicators. In turn, the endogenous nature of such revitalization area's delimitation can function as an advantage. The local population knows their place of residence best and is aware which areas require corrective actions, therefore such social sensitivity is as valuable as the quantitative approach to the discussed problems.

\section{Conclusion}

One more general, nevertheless important criterion should be mentioned - the areas designated for revitalization should present a significant importance for local development. The discussed delimitation procedures for degraded areas and the revitalization area are of used as examples and do not represent the only solution in this respect. Combined methods supported by desk research are also used. It seems crucial to match the delimitation process to the specificity of the municipality and the availability of reliable statistical data.

It is worth highlighting that the revitalization stakeholders have full access to all information, documents and participate in each of its stages (including delimitation), thus it is subject to civic control. Such control is manifested by exercising supervision over the functioning of public institutions, institutions of public trust, as well as increasing their transparency and respecting the rules of good governance. The described control results from the fact that processes associated with revitalization are usually carried out by public authorities, local governments, as the leaders, along with the support of private sector entities.

\section{Bibliography}

Allen M., 2001, Analysing the Organisational Environment, Select Knowledge Limited, Hertfordshire. Bartniczak B., Raszkowski A., 2017, Sustainable development in the Russian Federation - indicator-based approach, Problemy Ekorozwoju - Problems of Sustainable Development, vol. 13. no. 2, pp. 133-142.

Becker R., Collins R., 2003, Human Capital Investment, [in:] Wagner F., Joder T., Mumphrey A. (eds), Human Capital Investment for Central City Revitalisation, Routledge, New York.

Edwards M., Hulme D., 1995, NGO Performance and Accountability. Introduction and Overview, [in:] Edwards M., Hulme D. (eds), Non-governmental Organisations. Performance and Accountability. Beyond the Magic Bullet, Earthscan Publications, London. 
Fitzgerald J., Leigh N., 2002, Economic Revitalisation. Cases and Strategies for City and Suburb, SAGE Publications, Thousand Oaks.

Giorgetta S., 2002, The Right to a Healthy Environment, Human Rights and Sustainable Development, International Environmental Agreements: Politics, Law and Economics, vol. 2(2), pp. 173-194.

Głuszczuk D., Raszkowski A., 2015, Unemployment rate in the perspective of labour force survey and national employment offices - measurement problem based on the example of Polish regions, [in:] Löster T., Pavelka T. (eds), 9th International Days of Statistics and Economics, Libuše Macáková, Melandrium, Prague, pp. 467-476.

Kotler P., Asplund C., Rein I., Haider D., 1999, Marketing places in Europe: how to attract investments, industries, residents and visitors to cities, communities, regions and nations in Europe, Financial Times Prentice Hall, London.

Mitchell J., 2001, Business improvement districts and the "new" revitalisation of downtown, Economic Development Quarterly, vol. 15(2), pp. 115-123.

Pawłowski A., 2011, Sustainable Development as a Civilizational Revolution: A Multidisciplinary Approach to the Challenges of the 21st Century, CRC Press, Taylor \& Francis Group, London.

Przybyła Z., Przybyła K., 2014, Transformation of the Economic Base of a Town - the Case Study of Jelenia Góra, [in:] Jedlička P. (ed.), Hradec Economic Days 2014, Economic Development and Management of Regions, part IV, University of Hradec Králové, Hradec Králové, pp. 208-214.

Raszkowski A., Głuszczuk D., 2015, Regional Creativity Factors. Towards New Dimensions of Regional Development, [in:] Löster T., Pavelka T. (eds.), 9th International Days of Statistics and Economics, Libuše Macáková, Melandrium, Prague, pp. 1375-1385.

Ruffin F., 2010, Collaborative Network Management for Urban Revitalisation: The Business Improvement District Model, Public Performance \& Management Review, vol. 33(3), pp. 459-487.

Starr F., 2013, Corporate Responsibility for Cultural Heritage: Conservation, Sustainable Development, and Corporate Reputation, Routledge Studies of Heritage, New York.

Sutton S., 2010, Rethinking commercial revitalisation: a neighborhood small business perspective, Economic Development Quarterly, vol. 24(4), pp. 352-371. 